\title{
Liberalization of China-US Air Transport Market: Assessing the Impacts of the 2004 and 2007 Protocols
}

\author{
Zheng Lei ${ }^{1}$, Man $\mathrm{Yu}^{2}$, Ruowei Chen ${ }^{3}$, John F. O'Connell ${ }^{21}$ \\ ${ }^{1}$ Centre for Aviation Research, University of Surrey, UK \\ ${ }^{2}$ School of Aerospace, Transport and Management, Cranfield University, UK \\ ${ }^{3}$ Shanghai Aircraft Design and Research Institute, COMAC, China
}

\begin{abstract}
This paper examines China's considerations in reaching the 2004 and 2007 Air Service Agreement Protocols with the United States (US) and the impacts of such policy on the China-US market from the perspective of China. Analysis shows that the 2004 and the 2007 Protocols have profound impacts on the China-US market. The two Protocols have been associated with phenomenal traffic growth and intensified competition. Passengers also benefit from much more choice in terms of both airlines and routing. Over time, Chinese carriers' operating performance and financial performance have gradually improved after the liberalization expressed in the Protocols. However, the industry's hub-building initiatives are still seriously challenged by competing hubs in Seoul and Tokyo which have diverted substantial number of passengers moving between the China and US markets. Such issues have to be addressed in order to create a win-win outcome for both countries.
\end{abstract}

Key Words: China-US market, 2004 Protocol, 2007 Protocol, liberalization

\section{Introduction}

Since the first Open Skies agreement was signed between the United States (US) and the Netherlands in 1978, the US has been making every possible effort to expand its Open Skies partners around the world. China, as one of the fastest growing aviation markets and economies, as well as US's key trading partner, is among its top priorities. The years 2004 and 2007 represented significant breakthroughs in US-China negotiations with two Protocols being signed which radically liberalized traffic rights arrangements between the two countries

\footnotetext{
${ }^{1}$ Corresponding author. Tel 00441234754247

E-Mail address: frankie.oconnell@cranfield.ac.uk
} 
and transformed what was a highly restrictive bilateral regime to a more liberal market. This paper examines China's considerations in reaching the 2004 and 2007 protocols and the impacts of such policy on the China-US aviation market, as seen from the perspective of China. The study contributes to the literature on liberalization by providing much needed insights into the liberalization between the two largest aviation markets in the world. The rest of this paper is structured as follows. Section 2 reviews China's policy and experience of domestic deregulation and international liberalization. Section 3 examines the evolution of the China-US air service agreements. Section 4 analyses China's considerations in reaching the 2004 and 2007 Protocols. Section 5 assesses the impacts of the two protocols from China's perspective. And finally, Section 6 concludes the paper.

\section{China's Policy and Experience of Domestic Deregulation and International}

\section{Liberalization}

Founded in early 1950s, China's airline industry was controlled by the military through the Civil Aviation Administration of China (CAAC), a division of the Air Force. This organization was then separated from the military and became a civilian authority directly under the State Council of China in 1980, with six regional administrative bureaus created at the same time. Between 1980 and 1986, CAAC acted not only as an industry regulator, but also as the owner of the country's sole airline (CAAC) engaged in its day-to-day operations. All aspects of the industry, such as market entry, route authority, frequencies, fare, aircraft purchasing, funding and even passenger eligibility for taking flights, heavily controlled by this government agency (Zhang and Chen, 2003). Such a centralized system was challenged by the rapid air traffic growth starting from the mid-1980s, and the industry was decentralized with a number of new airlines established and various reforms taking place after 1986. A particular noteworthy reform was airline consolidation in 2002 where nine CAAC-controlled airlines were consolidated into three airline groups, namely, Air China, China Eastern and China Southern airlines. After the 2002 airline consolidation, the Chinese government gradually deregulated the domestic market; carriers were given greater freedom on route entry and more power to determine their own airfares (Lei and O'Connell, 2011). During this process, CAAC completed its own transformation from both a regulator and an operator to a pure industry watchdog.

As airline consolidation was completed in 2005, CAAC also removed its restrictions on private investment for domestic airlines. By the end of 2008, CAAC approved 14 new 
scheduled passenger airlines, with the majority of them being controlled by domestic private investors (Lei and O'Connell, 2011). The entry of the new carriers has intensified competition in the domestic market. By the end of 2014, airlines in the domestic market in China have enjoyed a high degree of freedom in route entry, subject to slot availability, and are able to set prices at market determined levels. Premium fares in China were completely deregulated in 2012, although a cap on economy class fares in the domestic market, designed to protect consumers, was still in place in 2015 .

In the international market, China was guided by a conservative policy until the late 1990s. Its policy aim was to protect the interests of its own carriers. This was partly because air transport was considered as a political instrument to serve China's diplomatic needs, instead of a strategic sector in support of the country's economic development. Such mindset was gradually changed as the Chinese economy became increasingly integrated into the world economy and the country was more exposed to the outside world. In 2003, CAAC declared China's objective to liberalize its air transport market in a "proactive, progressive, orderly and safeguarded" manner, and to take a proactive attitude in embracing the trend of international liberalization. Since then, the industry regulator started to re-adjust its international policy in support of liberalization and international cooperation, and in the first several years took very radical steps forward. A fundamental change was that the interests of its own carriers would no longer be the sole and exclusive criteria for the government when negotiating traffic rights with foreign countries. At this time the key principles of CAAC's international air transport policy were as follows:

- To proactively embrace the trend of liberalization

- To support China's overall diplomatic policies

- To support the national Opening-up Strategy and the objectives of social and economic development

- To give special regard to meet the demand for international air transport required by the country's foreign trade and tourism

- To give special support to the western, northeast and central regions to establish and improve their international air links

- To strike a balance among national interests, public interests and industry interests

- To promote airport hub development in China

- To enhance overall competitiveness of the whole industry. (Han, 2014) 
As a result of the application of these new perspectives by 2014, China's international aviation policy had the following characteristics: (1) multiple designation was allowed with 86 countries among the 115 Air Service Agreements (ASAs); (2) 27 ASAs had open route schedules; (3) 21 ASAs have introduced unlimited capacity entitlements for 3rd and 4th freedom traffic rights for air cargo services; (4) cargo 5th traffic rights was agreed with eight countries (Han, 2014). China also agreed to relax pricing by adopting the "country of origin principle" or the "double-disapproval principle" (Han, 2014). Within these policy achievements, the 2004 Protocol with the US, and the subsequent 2007 Protocol, were the most remarkable and were regarded as milestones in the liberalization of China's aviation policy. After ten years of liberalization policy negotiations, the most liberal and flexible bilateral traffic rights regime was still the one with the US.

\section{Evolution of the China-US Air Services Agreement}

China and the US established diplomatic relations on 1 January, 1979. China-US aviation links

were formally established a year later by the signing of the bilateral Air Services Agreement. Two carriers from each side were allowed to operate on specific routes (Route A and Route $\mathrm{B}^{2}$ ) as shown in Table 1. Based on that simple start six amendments were made in 1982, 1992, 1995, 1999, 2004 and 2007. Among these changes the 2004 and the 2007 Protocols were regarded as China's most ambitious attempts in its international liberalization efforts and form the basis of the research outlined here.

Table 1 Highlights of China-US air services agreements in the 1980s

\begin{tabular}{|c|l|}
\hline Items & \multicolumn{1}{c|}{ Provisions } \\
\hline Routes & $\begin{array}{l}\text { Route A: Beijing-Shanghai-Tokyo/or another point in Japan-Honolulu-Los } \\
\text { Angeles-San Francisco-New York }\end{array}$ \\
& $\begin{array}{l}\text { Route B: Beijing-Guangzhou-Shanghai-Tokyo/or another point in Japan- } \\
\text { Honolulu/or Seattle-Los Angeles-San Francisco-Chicago }\end{array}$ \\
\hline Designation & Two for each side \\
\hline Frequencies & $\begin{array}{l}\text { Two weekly frequencies for each side } \\
\text { Increased to six by the end of the 1980s }\end{array}$ \\
\hline
\end{tabular}

Source: US Department of State 1980-82. Note: Based on 1980-1982 China-US ASA

\footnotetext{
${ }^{2}$ Specific points of Route B were not agreed until the 1982 amendment was made.
} 
The four years preceding the 2004 negotiations between China and the US witnessed robust growth of bilateral travel, especially after 2001 when China joined the World Trade Organization (WTO). There was an average 10\% annual passenger growth rate, and $28 \%$ for air cargo (DOT, 1999-2003). Driven by this booming market, US carriers were keen to further expand their operations, but found themselves constrained by the capacity entitlements in the existing ASA and they collectively used up all the 54 weekly frequencies by 2001, only two years after the 1999 Protocol was signed. Faced with growing demand but constrained by regulatory restrictions, the only solution for US carriers was to apply for additional flights.

By contrast, Chinese carriers were less enthusiastic in providing further capacity on the routes. One possible reason was the difference in terms of overall strength compared with their US counterparts. The combined international operations produced by the Chinese airline industry as a whole was approximately 10.3 billion revenue passenger miles in 2000 , less than half of that performed by either United's or Northwest's Pacific operations for the same period (Meyer, 2002). Also China's total international traffic (measured by revenue tonne kilometres) accounted for only one eighth of that of the US side in 2002 (CAAC, 2003). Another reason might be that Chinese carriers were pre-occupied with the lucrative domestic market that had emerged from domestic liberalization, where the profit was much higher compared with international operations. At the same time, the poor financial performance of Chinese airlines in 2001, illustrated by losses totalling nearly US\$10 million for the top three carriers, made the industry even more cautious about capacity expansion, especially in the China-US market, where the Chinese side was losing money over the years, as confirmed by Wang Ronghu, the then Director General of CAAC's International Department, and the mastermind of the 2004 Protocol (Caijing, 2004). As a result, the Chinese side only performed 44 weekly frequencies, $81 \%$ of its 54 entitlement up until the 2003 summer schedule.

After several rounds of tough negotiations, the 2004 Protocols were eventually reached. Key provisions are summarized in Table 2. As can be seen in the comparison between the ASAs in 1999 and in 2004, the new Protocol was a significant development in China-US aviation relations. Designation was increased from four to nine airlines from each side. Access points were increased from 5 points in China and 12 points in the US for Route A (combination and 
all cargo services) to any point in China and any point in the US open to scheduled international services. Weekly frequencies were increased by 195 (111 for all-cargo operations and 84 for combination services) from 54 to 249 for each side by 2010 through phased-in manner. 
Table 2 Key features of China-US air services agreements in 1999, 2004 and 2007

\begin{tabular}{|c|c|c|c|}
\hline Key Features & 1999 Protocol & 2004 Protocol & 2007 Protocol \\
\hline Designation & Four airlines from each side & $\begin{array}{l}\text { Nine airlines from each side by } \\
2010 \text { through phased-in manner }\end{array}$ & $\begin{array}{l}\text { China may designate an unlimited } \\
\text { airlines as of } 1 \text { August } 2007 \text {; US may } \\
\text { designate an unlimited airlines on Route } \\
\text { B as of } 25 \text { March } 2011 \text {; no limitation on } \\
\text { designation to China Zone } 3\end{array}$ \\
\hline Access points & $\begin{array}{l}\text { Route A (combination and all cargo } \\
\text { services): US airlines - } 5 \text { points in } \\
\text { China; Chinese airlines - } 12 \text { points in } \\
\text { the US. Route B (all cargo services): } \\
\text { any points in the US or China, via any } \\
\text { intermediate points, and beyond to any } \\
\text { points outside China or US. }\end{array}$ & $\begin{array}{l}\text { Between any point in China and } \\
\text { any point in the US open to } \\
\text { scheduled international services; } \\
\text { US airlines are allowed to set up } \\
\text { cargo hubs within China }\end{array}$ & Same as 2004 Protocol \\
\hline Capacity/frequency & $\begin{array}{l}54 \text { weekly frequencies for each side by } \\
1 \text { April } 2001 \text { through phased-in } \\
\text { manner. }\end{array}$ & $\begin{array}{l}249 \text { weekly frequencies for each } \\
\text { side by } 2010 \text { through phased-in } \\
\text { manner; no frequency limitations } \\
\text { for points in China Zone } 3\end{array}$ & $\begin{array}{l}\text { An additional } 70 \text { weekly passenger } \\
\text { frequencies to China Zone } 1 \text { and Zone } 2 \\
\text { by each side by March 2012; no } \\
\text { frequency limitations for cargo as of } \\
\text { March 2011; no frequency limitation } \\
\text { for points in China Zone } 3\end{array}$ \\
\hline Tariffs & Double approval & Double-disapproval & Double-disapproval \\
\hline
\end{tabular}

Source: US Department of State, 1999, 2004, 2007.

Note: Based on China-US ASA in 1999, 2004, and 2007 
It is noteworthy that Chinese aviation market was divided into three zones when details of frequencies were specified, as can be seen in table 2. Beijing, Shanghai and Guangzhou made up Zone 1, points in eastern and coastal regions ( Anhui, Fujian, Guangdong (except Guangzhou), Hebei, Henan, Hubei, Hunan, Jiangsu, Jiangxi, Shangdong, Shanxi, Tianjin, and Zhejiang) were designated as Zone 2, and points in central, western and northeast regions, ( Chongqing, Gansu, Guangxi, Guizhou, Heilongjiang, Inner Mongolia, Jilin, Liaoning, Ningxia, Qinghai, Shaanxi, Sichuan, Tibet, Xinjiang and Yunnan, plus Hainan Island) made up as Zone 3. Interestingly, such a geographic division is only applied to the Chinese market; the US was seen as a single market of many potential city markets. The classification is mainly based on the different stages of economic development where Zone 1 is the most developed region in China followed by Zone 2, while Zone 3 is the least developed region and the arrangement reflected CAAC's policy of giving special international air transport support to the western, northeast and central regions, as described in Section 2. So there was a 249-frequency cap in Zone 1 and Zone 2, with no limitation at all for any operations in Zone 3. Moreover, China's outbound traffic is mainly concentrated in Beijing, Shanghai, and Guangzhou. Limiting frequencies to those cities protected the operations of Chinese airlines.

There are several other important aspects of the 2004 Protocol. It was the first time that foreign carriers were allowed to set up cargo hubs in China with full traffic rights. The relaxation on pricing control from double-approval to double-disapproval was unusual for China, given the Chinese legacy of market regulation and the weak financial performance of its major airlines. Furthermore, domestic, bilateral and third-country code-sharing were allowed though third country code-sharing of either Party needs to be agreed by airlines of the other Party, and is still subject to government approval on a case-by-case basis. Another important development not visible in Table 2 is that restrictions on commercial activities, including change of gauge and self-handling were relaxed in phased-in manner (US Department of State, 2004). Although the 2004 Protocol was not a full "Open Skies" that the US had aimed at, it was the most liberal agreement China had ever signed with a major trading partner and was described as a "Free Skies" deal by the US (Field, 2004) since it effectively created a regional "Open Skies" with China (Beane, 2007).

Additionally, an innovation of the 2004 Protocol was that it outlined a timetable for further discussions which were scheduled to be held in 2006 (US Department of State, 2004), hence becoming an obligation for the Chinese side. After further rounds of bargaining, the ASA was revised in 2007, further removing restrictions on designation, capacity and cargo operations, while retaining essential restrictions about charter operations, third-country code- 
sharing and passenger $5^{\text {th }}$ traffic rights (US Department of State, 2007). The entries in Table 2 show that designation would be liberalized for China as of 1 August 2007 and the same would apply to the US on Route B staring from March 2011. On the basis of the 2004 capacity entitlement, an additional 70 weekly passenger frequencies to China Zone 1 and Zone 2 could be added by each side by March 2012, while the cargo frequency cap would be removed as of March 2011. Operations to China Zone 3 would be fully liberalized, i.e. no limitations on either designation or frequencies for both sides. Furthermore, both sides acknowledged their mutual, ultimate objective as the full liberalization of their bilateral air transport market, and also promised to work together with each other to reach a new agreement as soon as possible (US Department of State, 2007).

\section{China's Considerations in Reaching the 2004 and 2007 Protocols}

Acknowledging the very substantial differences in the scale of the airlines as well as in the economic and policy systems of the two nations involved, it is perhaps surprising that the changes in the ASAs outlined above have been achieved in such a short time. The aspirations of the US side here seem easier to understand as they have adopted a consistent stance on open skies in ASA negotiations. However, insight on China's position is less well developed. This Section analyses China's considerations in reaching the 2004 and 2007 protocols based on CAAC's international air transport policy as outlined in Section 2.

A first step in understanding the negotiations, and their outcome, requires an understanding of the political context at the time. Serving China's political and diplomatic needs, and enhancing China-US national relations, both appear to be an important considerations for China in reaching the 2004 and 2007 Protocols. A strong bilateral relationship with the US was seen at the time a top priority for China, and traffic rights arrangements played an important part of the country's overall diplomacy policies. Therefore, in the process of opening up its international air transport market, China appeared to have seen liberalization arrangements with the US at the top of its agenda, in the belief that a more liberal bilateral air transport market would promote greater exchanges of people and goods, and so would lay a more solid foundation for further enhancing bilateral national relations. That policy stance reflected China's position at that time as it sought WTO membership; it may have believed 
that the US's support would be of paramount importance to achieve such a target (Prime, 2002). Furthermore, China was seeking to be elected as Part 1 member of the ICAO Council and any positive responses to ICAO's calls for liberalization would be helpful. As a matter of fact, China obtained its Part 1 membership in October 2004 (Xinhua, 2004), which, together with the 2004 Protocol, was among the most eye-catching achievements in China's aviation history.

A different political context surrounded the CAAC's approach to further liberalisation from 2006 inwards, as air transport was, for the first time, brought into the US-China Strategic Economic Dialogue $\left(\mathrm{SED}^{3}\right)$ framework at the US's request ${ }_{\circ}$ The SED was initiated in 2006 by US President George W. Bush and Chinese President Hu Jintao, representing the highestlevel bilateral forum between the two nations. An important objective of the SED is to provide a platform for senior officials to meet regularly for discussions of issues of strategic importance to both countries. By including traffic rights into SED negotiations the US was trying to overcome difficulties it believed it faced at the industry level (Williams, 2009). This was an influence upon the 2007 Protocol, as the aviation negotiations were under a sort of obligation to deliver some meaningful achievements in this broad strategic context (Russell, 2007). At the time bilateral air talks were specially timed by both sides with the aim of fitting any possible conclusions of agreements into the SED programme (Russell, 2007). Schofield (2007) argued that rights in aviation might even have been intentionally sacrificed to ensure US concessions in other areas, because when looked at in isolation, the Chinese were not well placed to achieve many positive gains from opening up their market further to US airlines.

A second consideration for China in the 2004 and 2007 Protocol negotiations involved concerns surrounding national development policy. Since 1999 the US had become China's largest trading partner, while China was evolved as the US's fifth largest trading partner in 2004, and its third largest one in 2007 (World Bank, 2015). From the perspective of economic development, it was imperative for China to accelerate its aviation liberalization to attract more US investment and further strengthen trade ties. China was one of very few US's major trading partners that had not signed an Open Skies agreement with it (DOS, 2011). Besides, China's trade volume was projected to increase rapidly and continuously in

\footnotetext{
${ }^{3}$ US-China Strategic Economic Dialogue (SED) was renamed as US-China Strategic and Economic Dialogue (SE\&D) in 2009.
} 
years ahead and aviation was expected to play a critical role in that trade. For instance, the liberal cargo traffic rights were intended to support China's foreign trade and its exportoriented economy. As Chinese cargo carriers were traditionally weak and were unable to build cargo hubs themselves, the "cargo hub" clause of the 2004 Protocol aimed at encouraging US cargo operators to establish their hubs in China, so as to make China's overall investment, economic and trade environment more attractive. A study conducted by US Bureau of Transport Statistics (BTS) (2004) revealed that air freight was the fastest growing segment of the US cargo industry, and expansion of aviation opportunities between the two nations could facilitate export of US high tech and high-value goods to China. For China, the aviation relationship and cooperation with the US was vital, since further development of parts of Chinese industry still relied on its support and assistance of advanced US technology. It would also mean that more US airlines, businesses and travellers could take advantage of the growing trade between the two economies (HKTDC, 2004). Therefore, the US pushed its counterpart really hard through all negotiations on traffic rights arrangements, as an important part of the overall bilateral aviation relations, while the CAAC had a range of reasons to consider the US claims seriously.

Regional and urban considerations entered the Chinese perspective at this time as well. At the regional scale, the fully liberalized arrangements in China Zone 3 were designed to support China's attempt to boost regional economic and social advancement via the "West Development" and "Rejuvenation of the Northeast Region" strategies. Likewise, provincial governments, aiming at promoting local economy and inward investment through attracting more international flights, also pushed hard for further liberalization. In urban areas, major Chinese airports, especially those who have been aspired to become main hubs, were looking forward to as many international flights as possible, with those linking the US regarded as their top priority, no matter they would be operated by Chinese airlines or US carriers.

The concern with hubs entered the 2004 and 2007 negotiations as a desire to prevent traffic diversion to third countries. Wolf (2001) argues that regulation of an air transport market generates spill-over effects to other markets that are interconnected by route networks. Traffic diversion benefits countries which have already liberalized their air links not only on routes that are substitutes for the regulated one within the same market, but also in other markets. Consequently, a country, if still executing regulation with liberalized interconnected markets, runs the risk that its air links degenerate to merely spokes of hub operations in other countries. Such effects appear to have started to unfold in China. By the end of 2003, US had 
Open Skies agreements with ten Asian economies, including South Korea, Japan, Singapore, Malaysia, and Taiwan (DOS, 2011). These Open Skies deals played an important role in helping US carriers to develop their networks in the Asia Pacific region which had implications for the hub roles of certain airports. For instance, Korean Air and Japan Airlines Cargo operated between China and the US via Tokyo and Seoul respectively, using 6th traffic rights. In passenger traffic, Japan's Tokyo Narita airport and Korea's Incheon airport are well ahead of Chinese airports in hub competition. Such an advantage may be partly attributed to their more liberal international air transport policies, especially with the US, while China's more restrictive traffic rights regime up to 2004 may have facilitated hub building at these airports. Thus, one important consideration in China's approach to negotiations may have been to reduce third country traffic diversion and so support the industry's own hub building initiatives.

A final factor here might have been a decision by China to match attitudes to the global liberalization trend. Instead of waiting for its "closed door" to be knocked open, the industry regulator may have seen an opportunity to create stronger, more competitive and experienced airlines by exposing them to the fierce and head-to-head competition with their foreign counterparts.

\section{The Impacts of the 2004 and 2007 Protocols}

Most studies find that liberalisation of bilaterals triggered substantial traffic growth (GomezIbanez and Morgan, 1984; Dresner and Windle, 1995; Marlin, 1995; Maillebiau and Hansen, 1995; Piermartini and Rousova, 2008; Warnock-Smith and Morrell, 2008). Table 3 shows that China-US market follows the same pattern. The race among US airlines to get into the Chinese market was already heated before the 2004 Protocol was signed. Delta, American and Continental finally won the battle and got the new designations, while the incumbents also benefited by either launching new routes or increasing frequencies. Competition within the US for the additional 111 weekly cargo frequencies was even more intense as the Department of Transportation (DoT) received applications for more than 200 flights (Caijing, 2004). Finally, Fedex managed to increase its weekly flights by six and started hub building in Guangzhou. Polar Air Cargo launched a new all-cargo service as well. As to the Chinese airline industry, except for very few prospective entrants, such as Shanghai International 
Cargo, Yangtze River Express and Hainan Airlines, who benefited directly from this deal by obtaining China-US route licences, the general sentiment was panic. In the week following the agreement's signing, both China Eastern and China Southern saw their stock price diving, while that of their major US counterparts shooting up (Caijing, 2004).

Table 3 Evolution of number of passenger airlines and airport pairs in the China-US market

\begin{tabular}{|c|c|c|cc|cc|cc|}
\hline & \multicolumn{2}{|c|}{$\begin{array}{c}\text { Number of } \\
\text { Airlines }\end{array}$} & \multicolumn{6}{c|}{ Airport pairs } \\
\cline { 2 - 8 } & China & US & Total & $\begin{array}{c}\text { one } \\
\text { airline } \\
\text { only }\end{array}$ & $\begin{array}{c}\text { by } \\
\text { Chinese } \\
\text { carriers }\end{array}$ & $\begin{array}{c}\text { one } \\
\text { airline } \\
\text { only }\end{array}$ & $\begin{array}{c}\text { by US } \\
\text { carriers }\end{array}$ & $\begin{array}{c}\text { one } \\
\text { airline } \\
\text { only }\end{array}$ \\
\hline 2001 & 3 & 2 & 7 & 5 & 4 & 4 & 4 & 4 \\
2002 & 3 & 1 & 5 & 3 & 4 & 4 & 2 & 2 \\
2003 & 3 & 1 & 7 & 6 & 6 & 6 & 2 & 2 \\
2004 & 3 & 1 & 8 & 7 & 6 & 6 & 3 & 3 \\
2005 & 3 & 2 & 9 & 8 & 5 & 5 & 5 & 5 \\
2006 & 3 & 3 & 9 & 7 & 5 & 5 & 5 & 4 \\
2007 & 3 & 3 & 11 & 9 & 6 & 6 & 6 & 5 \\
2008 & 4 & 4 & 13 & 11 & 7 & 7 & 7 & 6 \\
2009 & 4 & 5 & 15 & 13 & 7 & 7 & 9 & 8 \\
2010 & 4 & 4 & 14 & 10 & 7 & 7 & 9 & 7 \\
2011 & 4 & 4 & 16 & 11 & 7 & 7 & 12 & 9 \\
2012 & 4 & 3 & 16 & 11 & 8 & 8 & 11 & 8 \\
2013 & 4 & 3 & 18 & 12 & 10 & 10 & 12 & 9 \\
2014 & 4 & 4 & 22 & 14 & 14 & 14 & 15 & 12 \\
\hline
\end{tabular}

Note: The data are for the direct flights in the China-US market.

Source: Compiled by the authors from OAG database.

Given access to more recent data it is now possible to explore the effect of this two stage liberalization on the market as it was operating in 2014. The impact of liberalization can be charted via the change in the number of airlines, and the city pairs flown. Table 3 shows that total number of designated airlines operating in the China-US market doubled from four in 2004 to eight in 2014 with the US recording the largest increase. Nevertheless, as airlines are competing mostly in the city-pair or airport-pair markets ${ }^{4}$, increased number of players does not necessarily mean more intensive competition. In fact the number of airport-pairs served in

\footnotetext{
4 "Airport-pair" is defined in this paper as two airports served by scheduled non-stop flights, with at least two weekly frequencies.
} 
the China-US market increased dramatically from 8 in 2004 to 22 in 2014, and those served by more than one carrier increased from 1 in 2004 to 8 in 2014 . While in the US, the rule of traffic right allocation is based on the best public interest, Table 3 clearly shows that China follows "one route, one airline" policy, so that only one airline from China is allowed to serve a route in the China-US market. The arrangement seems to protect Chinese airlines from internal competition, while boosting the potential of each US city market for the designated carrier.

Over half of the airport-pair markets were served by one airline only, which might suggest a lack of local competition as a result of the national liberalization. However, given the complexity of the domestic networks in both China and the US, connecting passengers account for a big share of the total traffic on each city pair. So in essence the routes themselves are in competition. As an illustration, a passenger travelling from Philadelphia to Beijing (where no direct flights are available), may travel through an east coast hub by connecting with United from Washington (IAD), Air China from New York (JFK) or Continental from Newark (EWR), or through the central region by travelling with United or American Airlines from Chicago (ORD). All the five options are of equal convenience, thus competing with each other for the passenger in question. Therefore, more routes served mean more choices for the public, and consequently increased competition among airlines.

Table 4 further shows the total number of weekly frequencies increased from 53 in 2004 to 251 in 2014 while the number of seats supplied in the market increased from 17,174 to 71,074 during the same period, or a $15.3 \%$ average annual growth, as opposed to $2.4 \%$ annual growth rate between 2001 to 2004. It is worth pointing out that US carriers' share of weekly seats declined substantially between 2002 and 2004. This is mainly due to a change in Northwest's Asian strategy. It operated 13 direct flights per week between US and China before the $11^{\text {th }}$ September 2001 attacks, but in 2002 all of them were routed via Tokyo using 5th traffic rights. Such a shift in operations had great impact on the total seats supplied by the US carriers as a whole, as Northwest was a major player in the China-US market. Another reason was that the September 2001 attacks led to a significant market contraction, especially from the US side.

The positive gain for the US out of the liberalization can be seen after 2004 as US carriers reversed Chinese airlines' dominant position by wining 54\% of the market share in 2005 in terms of weekly seats, which represented $78 \%$ growth rate against the previous year, while 
the growth rate for Chinese airlines was a mere $2 \%$. US carriers' dominant position persisted in the next few years with 2011 witnessed the largest (34 percentage points) between the two in terms of weekly seats. What is also worth mentioning is that the scope provided by the 2007 Protocol helped the US airlines withstand the impact of the global financial crisis as traffic growth in the China-US market was still positive growth in 2008, as opposed to a traffic decrease of over $15 \%$ in the US international market overall (DOT, 2008). For Chinese airlines there was a reduction in weekly seats between 2007 and 2009. Nevertheless, the Chinese side started to catch up from 2009 and by 2014, the market share of Chinese airlines in terms of weekly seats was equal with that of their US counterparts. A key reason behind the Chinese carriers' improvement of performance was that the number of Chinese passengers travelling to the US has increased dramatically in the past few years. When the initial decisions on liberalization were taken in 2004, 1.3 million US nationals travelled to China which was over six times greater than the number of Chinese travellers moving in the opposite direction (CNTA, 2005). Rapid economic growth in China, along with a relaxation of visa regulations for Chinese nationals has almost equalised the two flows. In 2013, the number of Chinese nationals travelling to the US increased to 1.97 million which was very close to the number (2.09 million) of US nationals travelled to China (CNTA, 2014). As Chinese travellers are more likely to fly with their home carriers, which have local marketing, culture and language advantages compared to the US airlines, the increased number of Chinese tourists certainly helped Chinese carriers expand their share of the China-US market.

A constraint on the US share of the Chinese market is the fact that the vast majority of US carriers' operations in China were limited to Beijing and Shanghai, as shown in Figure 1. Chengdu was the only city outside of Beijing and Shanghai directly served by a US carrier with 3 weekly flights operated by United Airlines from San Francisco in 2014. By contrast, Figure 2 shows that airports in the US served by Chinese airlines expanded from the traditional destinations in Los Angeles and San Francisco to now include Boston, Honolulu, Washington, Houston, New York, Chicago, and Seattle. Such change of landscape benefits Chinese airlines as most of the US airports served by Chinese airlines have spare capacity, while the airports in Beijing and Shanghai are heavily congested and it is difficult to obtain additional slots, hence limiting US carriers' ability to expand capacity in the Chinese market. 
Figure 1 US carriers' seat capacity distribution at Chinese airports from 2001 and 2014

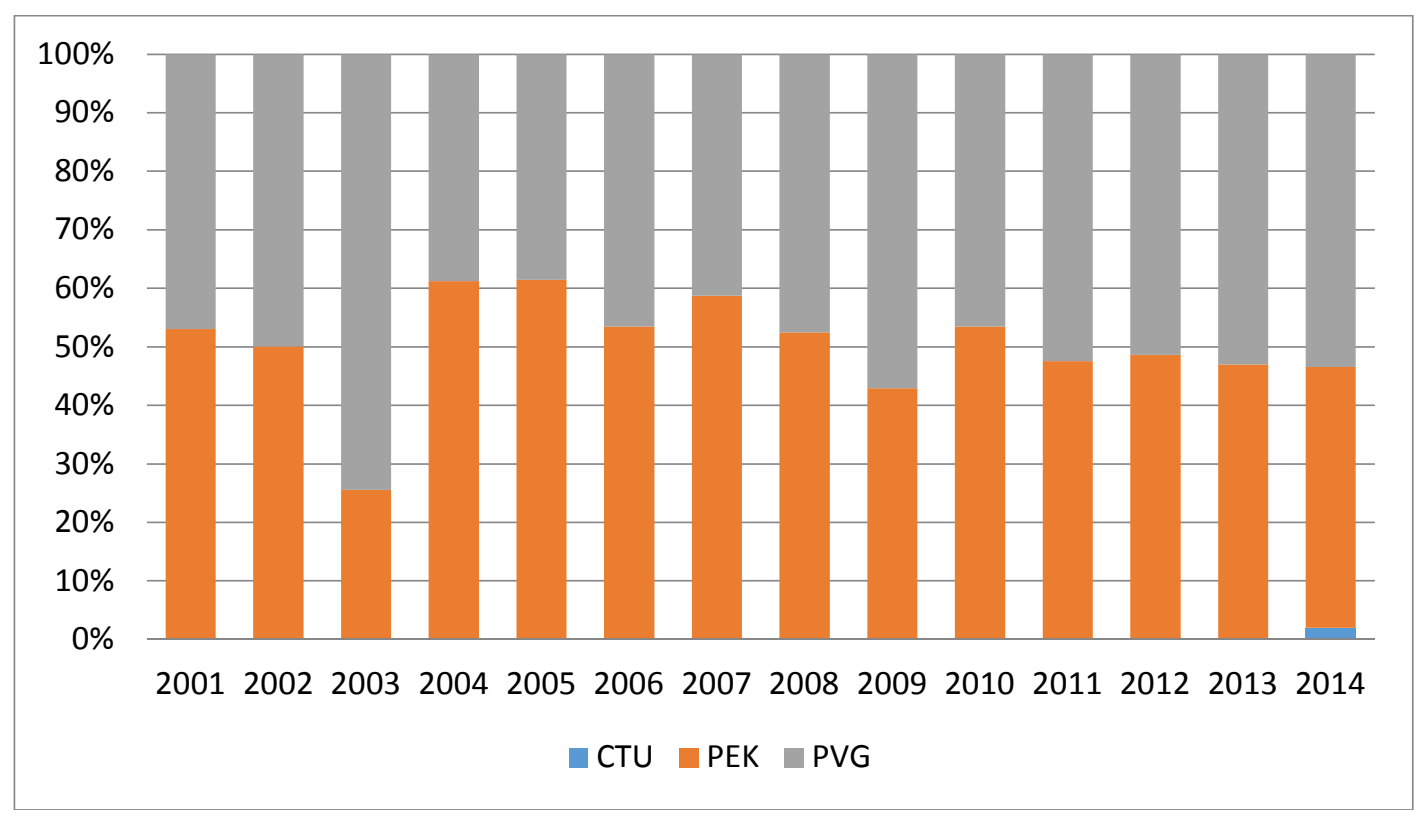

Note: $\quad \mathrm{CTU}=\mathrm{Chengdu}$ International Airport; PEK=Beijing International Airport; $\mathrm{PVG}=$ Shanghai Pudong International Airport. Source: OAG database.

Figure 2 Chinese carriers' seat capacity distribution at US airports from 2001 and 2014

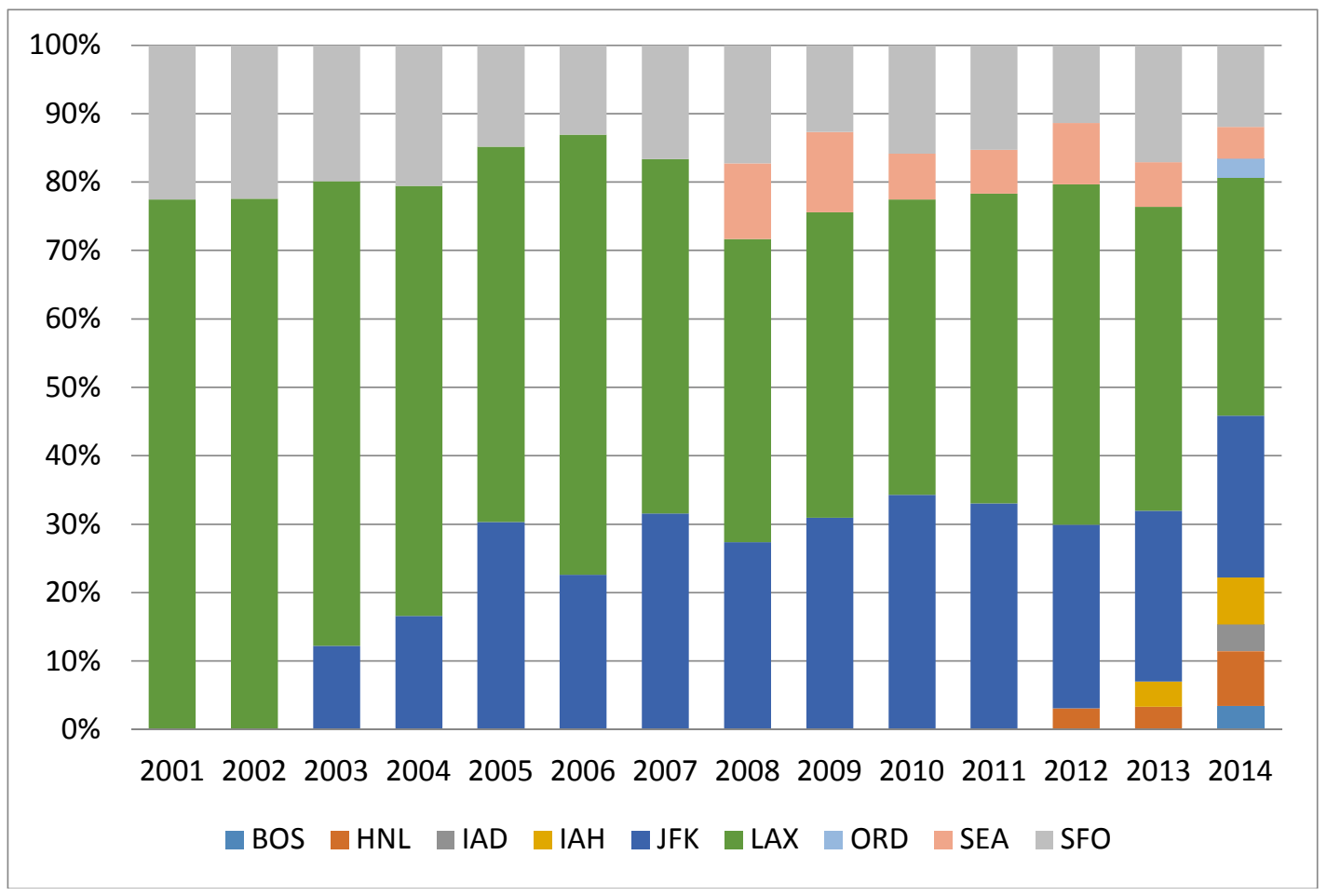

Note: BOS=Boston airport; $\mathrm{HNL}=$ Honolulu airport: IAD: Washington Dulles airport; $\mathrm{IAH}=$ Houston George Bush airport; JFK=New York John F Kennedy airport; LAX=Los Angel airport; ORD=Chicago O'Hare airport; SEA=Seattle airport; $\mathrm{SFO}=\mathrm{San}$ Francisco airport. Source: OAG database. 
Though US carriers were given unrestricted traffic rights to serve airports in China's more remote Zone 3 in 2007, US carriers appear to be unenthusiastic about serving airports outside of Beijing and Shanghai. This is understandable as most of the outbound traffic to the US is concentrated in Beijing and Shanghai which makes direct flights from other cities to the US not economically viable. As will be discussed below, these markets can also be served via code-share flights through Tokyo, Seoul and Hong Kong. Consequently, in recent years US carriers only managed to increase their weekly frequencies to China from 109 in 2011 to 129 in 2014 (see Table 4), while their Chinese rivals' weekly frequencies have more than doubled from 51 in 2011 to 122 in 2014. To summarize, a market boom driven by an increasing number of Chinese tourists, coupled with US carriers' difficulties of expanding capacity in the Chinese market, has resulted in US carriers gradually losing market share to their Chinese rivals. Such outcomes may have reflected CAAC's forward thinking when negotiating the 2004 and 2007 Protocols, especially as the initial impacts were firmly biased toward the US.

The cost of airfares is of course a major consideration in liberalization policies. Figure 3 shows monthly average ticket prices charged by Chinese and US carriers in the China-US market from 2008. These were actual prices charged extracted from IATA PaxIS database. As the full force of liberalization began to be felt, the fares charged by the Chinese carriers were almost $20 \%$ lower than their US counterparts during most of the period from January 2008 to March 2012. Nevertheless, fares charged by Chinese airlines have started to rise since April 2012. Between June 2012 and September 2012, the fares charged by Chinese carriers were on a par with their US counterparts, suggesting the improvement of financial performance of Chinese airlines. 
Figure 3 Average fares (US\$) of Chinese and US airlines in the China-US market

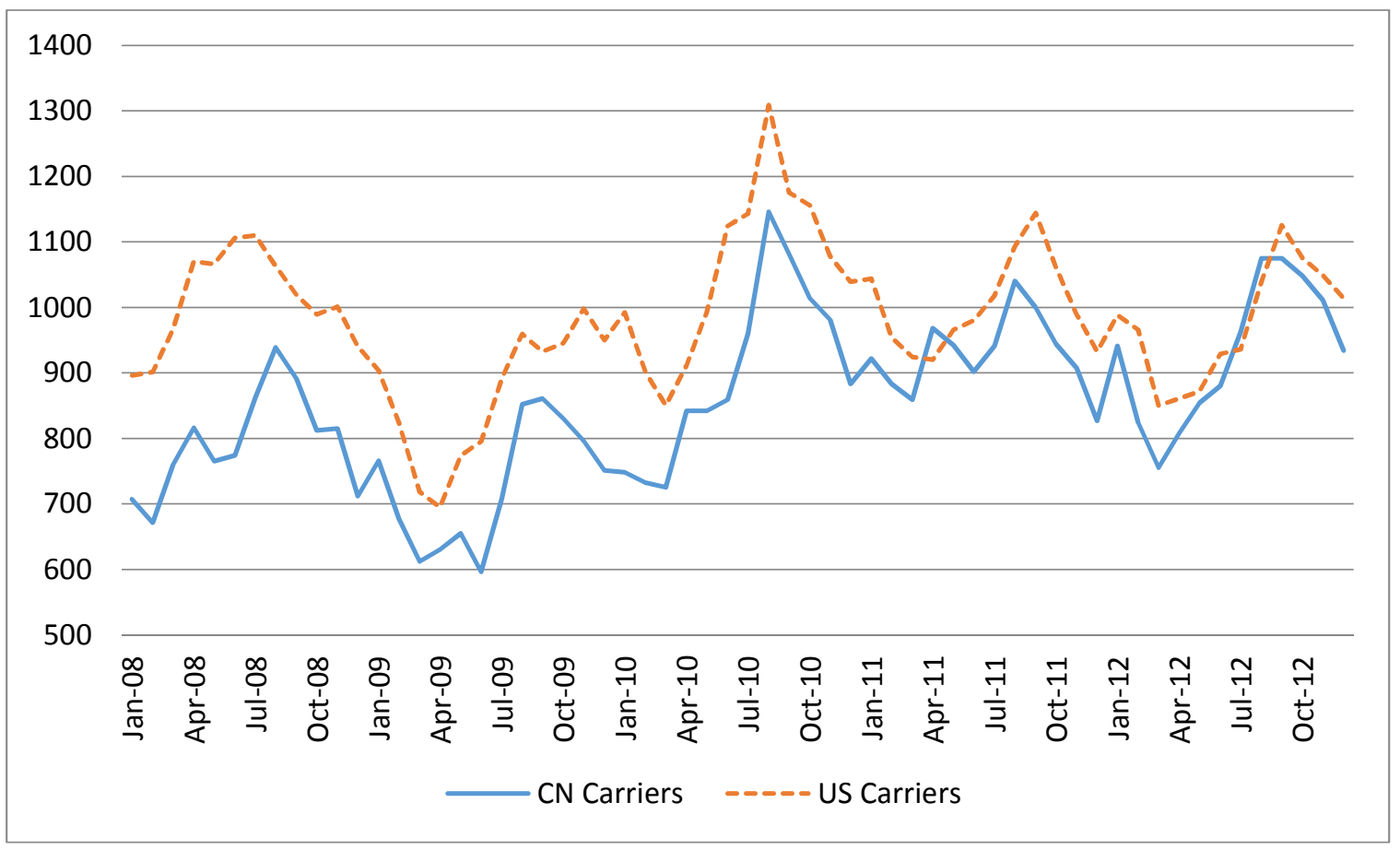

Source: PaxIS database

As previously discussed, an important consideration of China to liberalize its air transport market was to prevent third-country traffic diversion. However, Figure 4 reveals that passenger leakage to other hubs has worsened in the past few years. Passengers travelling in the China-US market more than doubled from 1.3 million in 2008 to 2.7 million in 2013 according to PaxIS database. In 2008, $14 \%$ of passengers travelling between China and the US were "lost" to other countries, of which over 97\% connected at Tokyo, Seoul and Hong Kong. By 2013 the ratio of passenger leakage to a third country increased to $20 \%$, of which $86 \%$ passengers were diverted through Seoul, Hong Kong and Tokyo. While Hong Kong is a Special Administrative Region of China, the loss of traffic to Seoul and Tokyo is an alarming finding for Chinese airports, whose hub building strategy has been seriously challenged. Such a high ratio of traffic leakage may be due to the following reasons. One is that US airlines traditionally use Tokyo as a hub for Asia Pacific traffic. Another reason is that airlines in Japan and Korea provide higher frequencies to more non-stop destinations in the US at lower prices than their Chinese counterparts (Fu et al, 2015), hence attracting substantial Chinese passengers transferring at Incheon and Narita. 
Figure 4. Traffic diversion in 2008 and 2013 in the China - US market

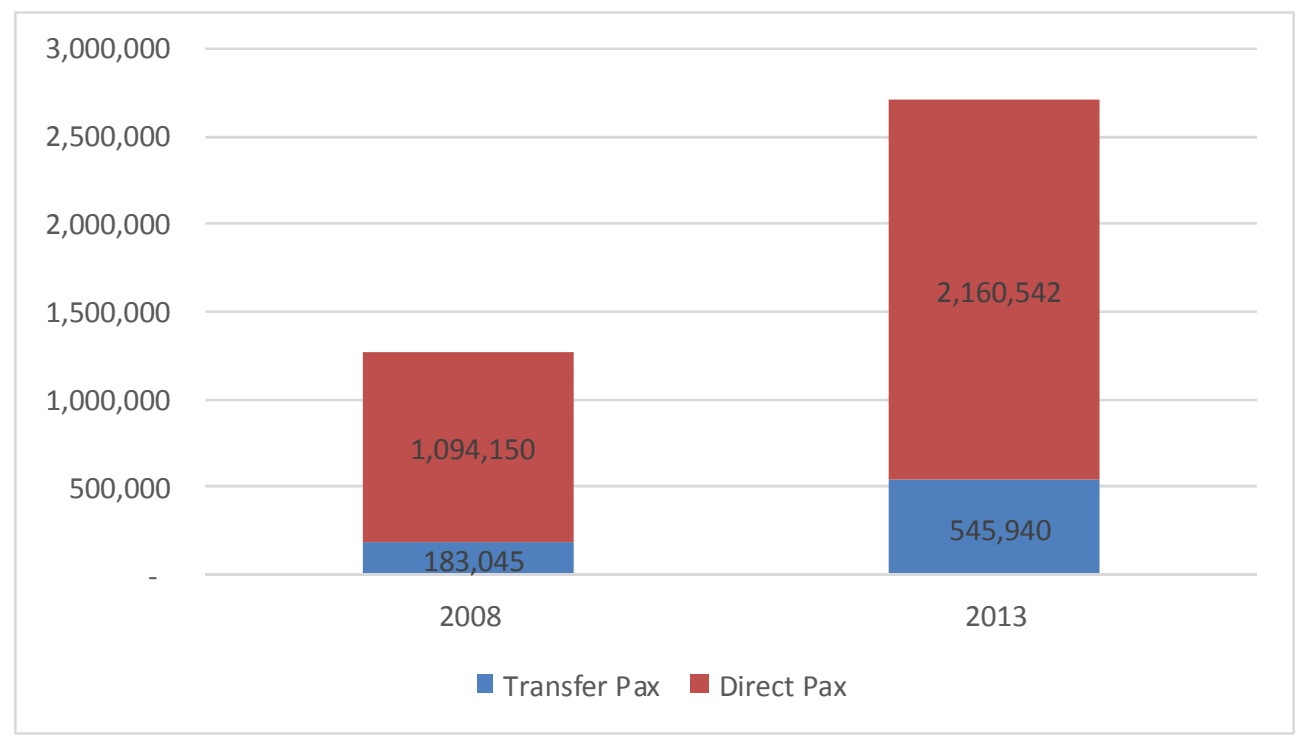

Source: PaxIS database

Table 4 Development of weekly frequencies \& weekly seats in the China-US market

\begin{tabular}{|c|c|c|c|c|c|c|c|c|c|c|}
\hline \multirow{2}{*}{ Year } & \multicolumn{9}{|c|}{ Weekly Frequency } & \multicolumn{4}{|c|}{ Weekly Seats } \\
\cline { 2 - 11 } & Total & $\begin{array}{c}\text { Chinese } \\
\text { carriers }\end{array}$ & $\begin{array}{c}\text { Share of } \\
\text { Chinese } \\
\text { Carrier }\end{array}$ & $\begin{array}{c}\text { US } \\
\text { carriers }\end{array}$ & $\begin{array}{c}\text { Share of } \\
\text { US } \\
\text { Carriers }\end{array}$ & Total & $\begin{array}{c}\text { Chinese } \\
\text { carriers }\end{array}$ & $\begin{array}{c}\text { Share of } \\
\text { Chinese } \\
\text { Carrier }\end{array}$ & $\begin{array}{c}\text { US } \\
\text { carriers }\end{array}$ & $\begin{array}{c}\text { Share of } \\
\text { US } \\
\text { Carriers }\end{array}$ \\
\hline 2001 & 45 & 22 & $49 \%$ & 23 & $51 \%$ & 16,005 & 7,495 & $47 \%$ & 8,510 & $53 \%$ \\
\hline 2002 & 37 & 21 & $57 \%$ & 16 & $43 \%$ & 12,612 & 7,226 & $57 \%$ & 5,386 & $43 \%$ \\
\hline 2003 & 22 & 15 & $68 \%$ & 8 & $36 \%$ & 6,952 & 4,418 & $64 \%$ & 2,534 & $36 \%$ \\
\hline 2004 & 53 & 30 & $57 \%$ & 23 & $43 \%$ & 17,174 & 10,238 & $60 \%$ & 6,936 & $40 \%$ \\
\hline 2005 & 70 & 31 & $44 \%$ & 39 & $56 \%$ & 22,798 & 10,468 & $46 \%$ & 12,330 & $54 \%$ \\
\hline 2006 & 83 & 37 & $45 \%$ & 47 & $57 \%$ & 25,960 & 11,801 & $45 \%$ & 14,159 & $55 \%$ \\
\hline 2007 & 95 & 41 & $43 \%$ & 54 & $57 \%$ & 30,485 & 13,016 & $43 \%$ & 17,469 & $57 \%$ \\
\hline 2008 & 102 & 40 & $39 \%$ & 62 & $61 \%$ & 32,436 & 12,890 & $40 \%$ & 19,546 & $60 \%$ \\
\hline 2010 & 112 & 41 & $37 \%$ & 71 & $63 \%$ & 35,582 & 12,798 & $36 \%$ & 22,784 & $64 \%$ \\
\hline 2011 & 131 & 48 & $37 \%$ & 83 & $63 \%$ & 40,140 & 14,999 & $37 \%$ & 25,142 & $63 \%$ \\
\hline 2012 & 160 & 51 & $32 \%$ & 109 & $68 \%$ & 47,278 & 15,585 & $33 \%$ & 31,693 & $67 \%$ \\
\hline 2013 & 171 & 64 & $37 \%$ & 106 & $62 \%$ & 48,378 & 19,112 & $40 \%$ & 29,267 & $60 \%$ \\
\hline 2014 & 251 & 121 & $41 \%$ & 116 & $59 \%$ & 56,747 & 25,313 & $45 \%$ & 31,434 & $55 \%$ \\
\hline
\end{tabular}

Note: the data are based on the first week of July in each year for direct passenger flights in the China-US market. Source: OAG database. 
The increasing traffic diversion through Japan and Korea makes US's demand for more liberal arrangements on third-country code-sharing unacceptable to China ( $\mathrm{Fu}$ et al, 2015). Both Japan and Korea have strong and mature networks serving China. Code-sharing with airlines in both countries enables US carriers to bypass Chinese frequency restrictions, and at the same time expand their presence in China without launching new routes. Those arrangements mean that there are difficulties facing China's policy of developing direct international air links to the US from China's secondary cities. Japan and Korea could also benefit from such operations, as the US could help them fill their aircraft by supplying transfer passengers. This would help them enhance their competitiveness on the China-Japan and China-Korea routes respectively, and further strengthen their advantages as Asian hubs.

\section{Summary and Conclusions}

Analysis shows that the 2004 and the 2007 Air Services Agreement Protocols have been associated with a profound impact on the China-US market. The two Protocols, along with the rapid economic expansion of China and its trade link with the US have facilitated phenomenal traffic growth, with frequency and seat capacity dramatically increased over their respective 2003 figures. At the same time, the level of competition appears to have intensified with the number of airlines in service increased, and the number of non-stop routes expanded dramatically. Although most of the routes are still operated by a single carrier, passengers have much more choice in terms of both airlines and routing. This is particularly so for the US where a hub-and-spoke network generally determines that the majority of traffic is transported through specific connections; one route added to a hub would add a number of routing options.

While US carriers made substantial gains in capturing market share from their Chinese counterparts in the first few years of liberalization, Chinese airlines have closed the gap quickly since 2010. Their financial performance in the China-US market has also improved over time. The changing competitive landscape in the China-US market is attributed to two factors. One is due to the rapid increase of Chinese outbound tourists to the US. The other is that Chinese airlines fly from Beijing and Shanghai to a large number of US airports, most of which still have spare capacity, while US carriers' operations in China are highly concentrated at capacity constrained airports in Beijing and Shanghai. Therefore, US carriers 
find it difficult to benefit from the booming China-US market by deploying more capacity on these routes. However, such a situation may change when Beijing's second airport schedules to opens in 2019. With planned capacity of 72 million passengers a year by 2025 and over 100 million passengers in the longer term, the new airport will add abundant capacity to the Beijing area $^{5}$ (Beijing New Airport Construction Headquarters, 2015). As a result of the relief of capacity constraints, US carriers may be able to schedule more flights to Beijing. For Chinese airlines, it is imperative for them to improve their underlying competitiveness in order to sustain their advantages in the China-US market.

This study also reveals that China's hub-building initiatives are seriously challenged by competing hubs in Seoul and Tokyo which have diverted substantial number of passengers in the China-US markets. A strategy which may be considered by Chinese airlines is to form joint ventures with their US counterparts. Such cooperation would allow airlines in China and the US to coordinate their routes, schedules, products and fares, which would, at least in theory, bring costs down, rationalise capacity input and improve competitive strength for both sides. If such benefits can be passed on to passengers by offering them lower fares or more value added products and services, this may make connecting flights via Seoul and Tokyo less attr-active. Furthermore, joint ventures may be more important to the Chinese side, since diverted traffic, generally speaking, is a price-sensitive segment, which constitutes the bulk of customers for Chinese airlines. Nevertheless, full joint ventures require anti-trust immunity from US Government which may not be granted until a China-US open skies agreement is signed to ensure consolidation is not anti-competitive. Having said that, the recent announcement of strategic partnership ${ }^{6}$ between Delta and China Easter seems to represent a

\footnotetext{
${ }^{5}$ Beijing's existing airport (Beijing Capital International Airport) handled 84 million passengers in 2014 (CAAC, 2015).

${ }^{6}$ Delta and China Eastern announced on $27 \mathrm{Jul} 2015$ that Delta is to acquire a 3.55\% stake in China Eastern for USD450 million. Both airlines announced that:
}

- $\quad$ "the parties will take advantage of their respective route networks, flight services, relevant businesses and advantageous resources to fully connect the world's two top economies as well as two top air transportation markets."

- $\quad$ "The parties wish, through excellent operation and international cooperation, to optimise customer experience, enhance the parties' global competitiveness and promotes the development and revenue growth of both parties."

- $\quad$ "We share a vision that will create the most profitable, enduring franchise between the U.S. and China, with world-class customer service" (CAPA, 2015) 
major step towards developing deeper and more powerful relationships (CAPA, 2015). Such issues may have to be considered in future negotiations between China and the US in order to create a win-win outcome for both countries.

\section{Acknowledgement:}

The authors gratefully acknowledge the constructive comments from Prof Kevin O'Connor. All remaining errors are ours.

\section{References}

Beane, A. (2007), “Aviation relations between the United States and China: are open skies on the horizon?" Journal of Air Law and Commerce, Vol. 72, Issue 4, p. 803-833.

Beijing New Airport Construction Headquarters (2015) Overview of Beijing New Airport, Beijing.

Prime, P. (2002), China joins the WTO: how, why and what now? Business Economics, Vol. XXXVII, No. 2 (April).

BTS (2004), Air freight is fastest growing segment of U.S. cargo economy; new study tracks trends in $\$ 29$ billion dollar-a-day cargo industry, available from:

http://www.bts.gov/press_releases/2004/bts017_04/html/bts017_04.html (accessed 15th Jun, 2011).

CAAC (2003) Statistical Data on Civil Aviation of China, Beijing: China Civil Aviation Publishing House.

CAAC (2015) Statistical Data on Civil Aviation of China, Beijing: China Civil Aviation Publishing House.

CAPA (2015) Delta Air Lines plans a China Eastern stake: will other US airlines follow the foreign equity path? Available from: http://centreforaviation.com/analysis/delta-air-lines- 
plans-a-china-eastern-stake-will-other-us-airlines-follow-the-foreign-equity-path-237144 (accessed 23 August 2015)

Caijing (2004), Sino-US air pact causes domestic panic, available from:

http://english.caijing.com.cn/2004-07-05/100043211.html (accessed 7th Jun, 2014).

CNTA (2005) Statistics of China Tourism in 2004 (in Chinese), Beijing: China National Tourism Administration.

CNTA (2014) Statistics of China Tourism in 2013 (in Chinese), Beijing: China National Tourism Administration.

DOS (2011), Open Skies partnerships: expanding the benefits of freer commercial aviation, available from: http://www.state.gov/r/pa/plrmo/159347.htm (accessed 2nd Aug, 2011).

DoT (various years), T-100 International Market, Washington: US Department of Transportation.

Dresner, M. and Windle, R. (1995), “Are U.S. carriers to be feared? Implication of hubbing to north Atlantic competition", Transport Policy, Vol. 2, No. 3, p. 195-202.

Field, D. (2004), "USA and China free markets", Airline business, Jul 2004, Vol. 20, Issue 7 , page 8 .

Fu, X., Oum, T., Chen, R. and Lei, Z. (2015) Dominant carrier performance and international liberalization - the case of Northeast Asia, Transport Policy (in press).

Gomez-Ibanez, J. and Morgan, I. (1984), "Deregulating international markets: the case of aviation and ocean shipping", Yale Journal on Regulation 2, 1984-1985, p. 107-144.

Han, J. (2014) China's approach for its international air cargo transport liberalization, ICAO Air Cargo Development Forum, 2-5 September, Zhenzhou, available from: http://www.icao.int/Meetings/AirCargoDevelopmentForum-2014/Documents/Session2_HanJun.pdf (accessed on 15 November 2014). 
HKTDC (2004), US, China Ink Landmark Air Service Agreement, available from: http://www.hktdc.com/info/mi/a/baus/en/1X00IAIO/1/Business-Alert---US/US--China-InkLandmark-Air-Service-Agreement.htm (accessed 15th Jun, 2011).

Lei, Z. and O'Connell, J. F. (2011), “The evolving landscape of Chinese aviation policies and impact of a deregulating environment on Chinese carriers", Journal of Transport Geography, Vol. 19, Issue 4, p. 829-839.

Maillebiau, E. and Hansen, M. (1995), "Demand and Consumer welfare impacts of international airline liberalization: the case of the North Atlantic", Journal of Transport Economic and Policy, Vol. 29, Issue 2, p. 115-136.

Marlin, P. (1995), "Competition in European aviation: pricing policy and market structure", The Journal of Industrial Economics, Vol. 43, No. 2, Jun 1995, p. 141-159.

Meyer, G. (2002), “U.S.-China aviation relations: flight path toward Open Skies?” Cornell International Law Journal, Vol. 35, Issue 2, p. 427-456.

Piermartini, R., Rousová, L. (2008). Liberalization of air transport services and passenger traffic. Staff Working Paper ERSD-2008-06, World Trade Organization, Economic Research and Statistics Division. Available at: https://www.wto.org/english/res_e/reser_e/ersd200806_e.pdf (accessed 11 August 2015).

Russell, E. (2007) China, US expand air traffic. Available at: http://www.atimes.com/atimes/China_Business/IE31Cb01.htm (accessed 11 August 2015).

Schofield, A. (2007), Peters urges Open Skies progress with China, available from: http://www.aviationweek.com/aw/jsp_includes/articlePrint.jsp?storyID=news/PETE04127.x ml\&headLine $=$ Peters $\% 20$ Urges $\% 20$ Open $\% 20$ Skies $\% 20$ Progress $\% 20 \mathrm{With} \% 20 \mathrm{China}$ (accessed 24th Jul, 2011). 
US Department of State (1980) US-China Air Transport Agreement of September 17, 1980, available from: http://www.state.gov/documents/organization/122714.pdf (access 1 November 2014).

US Department of State (1999) Protocol to the Agreement between the Government of the United States of America and the Government of the People's Republic of China relating to Civil Air Transport, available from: http://www.state.gov/e/eb/rls/othr/ata/c/ch/114163.htm (access 1 November 2014).

US Department of State (2004) Protocol to the Agreement between the Government of the United States of America and the Government of the People's Republic of China relating to Civil Air Transport, available from: http://www.state.gov/e/eb/rls/othr/ata/c/ch/114552.htm (access 1 November 2014).

US Department of State (2007) Protocol to Amend the Agreement between the Government of the United States of America and the Government of the People's Republic of China relating to Civil Air Transport, available from: http://www.state.gov/e/eb/rls/othr/ata/c/ch/114749.htm (access 1 November 2014).

Warnock-Smith, D., Morrell, P. (2008) Air transport liberalization and traffic growth in tourism-dependent economies: A case-history of some US-Caribbean markets, Journal of Air Transport Management, 14(2), 82-91.

Williams, A. (2009) Contemporary issues shaping China's Civil Aviation Policy, Ashgate: Aldershot.

World Bank (2015) World Integrated Trade Solution, World Bank.

Wolf, H. (2001), "Network effects of bilaterals: implications for the German air transport policy", Journal of Air Transport Management, Vol. 7, Issue 1, p. 63-74.

Xinhua. (2004) China elected as ICAO Part 1 Council member, available from: http://news.xinhuanet.com/fortune/2004-10/03/content_2049587.htm (accessed on 30 August 2015). 
Zhang, A. and Chen, H. (2003), "Evolution of China's Air Transport Development and Policy towards international liberalization”, Transportation Journal, Vol. 42, Issue 3, p. 31-49. 
2015-09-26

\section{Liberalization of China-US air transport market: assessing the impacts of the 2004 and 2007 protocols}

Zheng, Lei

Elsevier

Lei, Z., Yu, M., Chen, R. and O'Connell, J.F. 2016. Liberalization of China-US air transport market: assessing the impacts of the 2004 and 2007 protocols. Journal of transport geography, 50, pages 24-32.

https://dspace.lib.cranfield.ac.uk/handle/1826/10642

Downloaded from Cranfield Library Services E-Repository 